\title{
APLIKASI SIMULASI BERBASIS WEB UNTUK SUHU DAN KALOR PADA MATA PELAJARAN FISIKA BAGI SISWA SMA KELAS X
}

\author{
(1) Breat Prasetyo, ${ }^{(2)}$ Hafsah \\ ${ }^{(1,2)}$ Prodi. Teknik Informatika \\ Universitas Pembangunan Nasional "Veteran" Yogyakarta \\ Tambakbayan 2 Babarsari, Yogyakarta \\ email : hafsahotha@yahoo.com
}

\begin{abstract}
Physics is one of the subjects studied in high school. Many argue that one of the lessons of physics become less desirable, one reason because physics contains many abstract concepts and magnitudes. One material that is in high school physics is fluid mechanics, including fluid static and dynamic fluid. Static fluid include law pascal and archimedes law , while the law include the dynamic fluid continuity and Bernoulli law. During this learning method is applied mostly still conventional, inside delivery media still use the board as well as the extent of the image of the book. Still at least the lack of visualization of dynamic and interactive learning media that makes the lack of interest in learning physics, it made for a multimedia based simulation applications of fluid mechanics in physics. The method used in the design and manufacture of this application is the waterfall methodology and multimedia development stages. Software used in the making of this application is Adobe Flash CS3 with actionscript 2.0 programming language for multimedia applications. While web applications built using PHP and MySQL software.
\end{abstract}

Keywords: Physics, Web Application, Multimedia, Fluid Mechanics.

Fisika merupakan salah satu bidang studi yang dipelajari di sekolah menengah atas. Banyak yang berpendapat bahwa fisika menjadi salah satu pelajaran yang kurang diminati, salah satu penyebabnya karena fisika banyak mengandung konsep dan besaran yang abstrak. Salah satu materi yang ada di dalam fisika di sekolah menengah atas adalah mekanika fluida yang meliputi fluida statis dan fluida dinamis. Fluida statis meliputi hukum pascal dan hukum archimedes, sedangkan fluida dinamis meliputi hukum kontinuitas dan hukum bernoulli. Selama ini metode pembelajaran yang diterapkan kebanyakan masih bersifat konvensional, di dalam penyampaiannya masih menggunakan media papan tulis serta sebatas gambar dari buku. Masih sedikitnya visualisasi dinamis dan kurangnya media pembelajaran interaktif yang membuat kurangnya minat untuk belajar fisika, maka dibuat aplikasi simulasi berbasis multimedia untuk mekanika fluida pada fisika. Metode yang digunakan dalam perancangan dan pembuatan aplikasi ini adalah metodelogi waterfall dan tahap-tahap pengembangan multimedia. Software yang digunakan dalam pembuatan aplikasi ini adalah Adobe Flash CS3 dengan bahasa pemograman actionscript 2.0 untuk aplikasi multimedia. Sedangkan aplikasi website dibuat dengan menggunakan perangkat lunak PHP dan MySQL.

Kata kunci : Fisika, Aplikasi Web, Multimedia, Mekanika Fluida.

\section{PENDAHULUAN}

Materi dalam sebuah pelajaran merupakan satu pokok yang sangat penting dalam proses belajar mengajar. Pembelajaran mempunyai aspek penting yang berhubungan langsung dengan cara-cara mengajar yang efektif dan efisien agar para siswa dapat mengerti dan memahami dengan jelas apa yang disampaikan pada mata pelajaran tersebut.

IImu fisika merupakan ilmu yang dipelajari di sekolah menengah atas. Banyak yang berpendapat bahwa fisika merupakan salah satu ilmu pelajaran yang kurang diminati, salah satu penyebabnya adalah fisika banyak mengandung konsep dan besaran yang abstrak, sehingga sukar untuk dibayangkan. Selama ini metode pembelajaran yang diterapkan masih bersifat konvensional, dalam penyampainnya masih menggunakan media papan tulis dan 
sebatas gambar dari buku. Metode pembelajaran ini memiliki beberapa kekurangan di antaranya tidak semua masalah fisika dapat disimulasikan di laboratorium.

Suatu informasi akan lebih jelas jika ditampilkan dalam sebuah media yang dapat menggabungkan berbagai bentuk informasi yang ada. Dengan adanya multimedia, manusia dapat berinteraksi dengan komputer melalui media gambar, teks, audio, video dan animasi sehingga informasi yang disajikan akan lebih menarik. Teknologi dapat digunakan dalam dunia pendidikan, karena multimedia itu sendiri bisa menjadi salah satu media pendukung dalam penyampaian informasi.

Salah satu yang dibahas pada pelajaran fisika adalah fluida atau zat yang dapat mengalir, sehingga yang masuk dalam kategori fluida adalah zat cair dan udara/gas. Dalam mekanika fluida terdapat 2 klasifikasi hukum, yaitu fluida statis dan fluida dinamis. Fluida statis mempelajari fluida pada keadaan diam sementara fluida dinamis mempelajari fluida yang bergerak. Pada fluida statis terdapat hukum Pascal dan hukum Archimedes, sedangkan pada fluida dinamis yaitu hukum Kontinuitas dan hukum Bernoulli. Untuk dapat memahami materi mekanika fluida maka diperlukan media pembelajaran pendukung yaitu aplikasi simulasi berbasis multimedia untuk mekanika fluida pada fisika yang dapat membantu seseorang yang dalam hal ini lebih difokuskan ke siswa tingkat SMA kelas XI. Simulasi ini dilengkapi dengan materi, simulasi dan visualisasi hukum-hukum pada mekanika fluida dan latihan soal.

\section{METODOLOGI PENELITIAN}

Metodologi penelitian yang dipakai adalah metode waterfall (air terjun) dan metode tahap-tahap pengembangan multimedia. Pada waterfall (air terjun) terdiri dari 6 tahap, yaitu rekayasa, analisis, desain, implementasi, pengujian, pemeliharaan. Dalam penelitian ini pada metode waterfall hanya sampai pada tahap pengujian. Sementara tahap-tahap pengembangan multimedia itu sendiri terdiri dari 6 tahap, yaitu concept, design, material collecting, assembly, testing, dan distribution. Dalam penelitian ini yang digunakan tahap design sampai tahap testing.

\section{DASAR TEORI}

\section{Konsep Dasar Mekanika Fluida}

Wujud zat secara umum dibedakan menjadi tiga, yaitu zat padat, zat cair, dan gas. Berdasarkan bentuk dan ukurannya, zat padat mempunyai bentuk dan volume tetap, zat cair memiliki volume tetap akan tetapi bentuknya berubah sesuai wadahnya, sedangkan gas tidak memiliki bentuk maupun volume yang tetap. Karena zat cair dan gas tidak mempertahankan bentuk yang tetap sehingga keduanya memiliki kemampuan untuk mengalir. Suatu fluida adalah zat yang dapat mengalir dan memberikan sedikit hambatan terhadap perubahan bentuk ketika mengalami tekanan (Supiyanto, 2005). Oleh karena itu, dari ketiga jenis zat tersebut yang termasuk fluida adalah zat cair dan gas.

\section{Fluida Statis (Hidrostatis)}

Fluida statis adalah fluida dalam keadaan diam atau fluida tak bergerak, misalnya air dalam gelas. Dalam fluida statis akan dipelajari hukum-hukum dasar yang dapat menjelaskan antara lain: mengapa makin dalam seseorang menyelam makin besar tekanan yang di alami, mengapa kapal laut yang terbuat dari besi dapat mengapung dipermukaan air laut, mengapa kapal selam dapat melayang, mengapung, dan tenggelam dalam air laut.

Jika gaya sebesar $F$ bekerja secara merata dan tegak lurus pada suatu permukaan yang luasnya $A$, maka tekanan $P$ pada permukaan itu dirumuskan sebagai

$$
P=\frac{F}{A}
$$

dengan :

$$
\begin{aligned}
& P=\text { tekanan }\left(\mathrm{N} / \mathrm{m}^{2}\right) \\
& F=\text { gaya pada permukaan }(\mathrm{N}) \\
& A=\text { luas permukaan }\left(\mathbf{m}^{2}\right)
\end{aligned}
$$

\section{Hukum Pascal}

Blaise Pascal, seorang ilmuwan Perancis menyatakan bahwa ketika perubahan tekanan diberikan pada suatu fluida pada ruang tertutup, perubahan tersebut akan diteruskan sama besar kesegala arah, seperti yang terjadi pada percobaan dengan menggunakan 
penyemprot Pascal (Gambar 1). Pernyataan ini akhirnya dikenal sebagai hukum Pascal (Supiyanto, 2005).

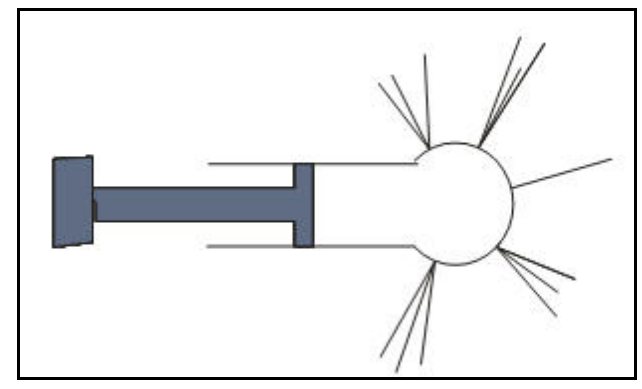

Gambar 1. Tabung penyemprot Pascal

Jika misalnya zat cair diberi tekanan sebesar $P$, maka setiap bagian zat cair dan dinding bejana mengalami tekanan sebesar $P$. Jadi, hukum Pascal dapat dinyatakan sebagai berikut: tekanan yang diadakan dari luar kepada zat cair yang ada di dalam ruangan tertutup akan diteruskan oleh zat cair itu ke segala arah dengan sama rata.

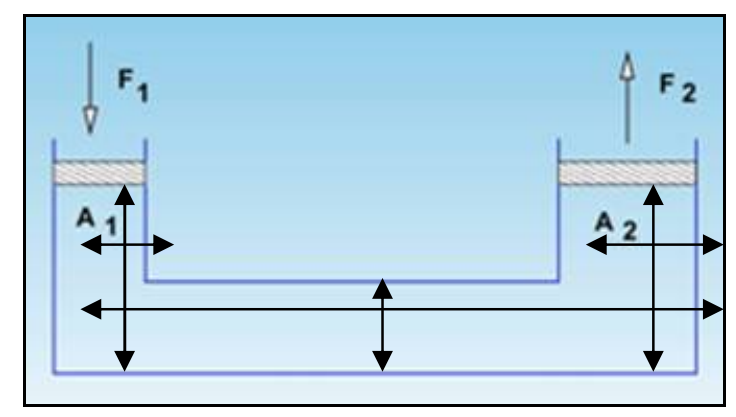

Gambar 2. Bejana untuk menyelidiki hukum Pascal

Dari hukum pascal ini diperoleh prinsip bahwa dengan gaya kecil dapat dihasilkan gaya yang lebih besar. Untuk memahami hukum pascal ini dengan lebih baik, maka tinjau hukum pascal ini secara kuantitatif, yaitu dengan menggunakan angka-angka atau besaranbesaran. Untuk itu tinjau sebuah alat yang bentuknya seperti pada Gambar 2. Alat itu berupa bejana tertutup yang dilengkapi dengan dua buah torak (pengisap) yang luas penampangnya berbeda, yaitu $A_{1}$ dan $A_{2}\left(A_{1} \leqslant A_{2}\right)$. Untuk menyederhanakannya anggaplah bahwa antara torak dan dinding tidak ada gesekan. Di dalam bejana terdapat zat cair. Diumpamakan torak yang luasnya $A_{1}$ dikerjakan gaya sebesar $F_{1}$ yang arahnya ke bawah. Karena itu, zat cair di dalam bejana mengalami tekanan

$$
P=\frac{F_{1}}{A_{1}}
$$

Tekanan $P$ ini diteruskan sama rata ke segala arah di dalam bejana seperti yang digambarkan pada Gambar 2.8, termasuk pada torak yang luasnya $\boldsymbol{A}_{2}$ (torak disebelah kanan). Dengan ini maka dapat menghitung gaya yang di alami oleh torak di sebelah kanan dengan mengalikan tekanan $P$ dengan luas penampang torak $A_{2}$. Jika gaya itu di sebut $F_{2}$, maka

$$
F_{2}=P A_{2}=\frac{F_{1}}{A_{1}} A_{2}
$$

Dari persamaan ini diperoleh

$$
\frac{F_{1}}{A_{1}}=\frac{F_{2}}{A_{2}}
$$




\section{Hukum Archimedes}

Sebuah benda yang diletakan di dalam air terasa lebih ringan dibandingkan dengan beratnya ketika di udara. Jika benda dicelupkan ke dalam zat cair, sesungguhnya berat benda itu tidaklah berkurang. Gaya tarik bumi kepada benda itu besarnya tetap. Akan tetapi zat cair mengadakan gaya yang arahnya ke atas kepada setiap benda yang tercelup di dalamnya. Ini menyebabkan berat benda seakan-akan berkurang. Secara umum hukum Archimedes dapat dinyatakan sebagai berikut: sebuah benda yang tercelup sebagian atau seluruhnya ke dalam zat cair akan mengalami gaya ke atas yang besarnya sama dengan berat zat cair yang dipindahkan (Supiyanto, 2005).

Menghitung gaya ke atas di dalam zat cair dapat dihitung sebagai berikut: gaya ke atas $=$ berat fluida yang dipindahkan. Jadi

$$
F_{a}=m_{f} g
$$

$$
F_{a}=p_{f} V_{b f} g
$$

dengan $\rho_{f}=$ massa jenis fluida $\left(\mathrm{kg} / \mathrm{m}^{2}\right), V_{b f}=$ volume benda yang tercelup dalam fluida $\left(\mathrm{m}^{3}\right)$, dan $\mathrm{g}$ adalah percepatan gravitasi $\left(9.8 \mathrm{~m} / \mathrm{s}^{2}\right)$. Volume benda yang tercelup dalam fluida adalah $V_{b f}$. Jika benda tercelup seluruhnya dalam fluida, maka $V_{b f}=V_{b}\left(V_{b}=\right.$ volume benda $)$. Jika benda tercelup setengah bagian dalam fluida, maka $V_{b f}=\frac{1}{2} V_{b}$

\section{Hukum Kontinuitas}

Persamaan kontinuitas berbunyi pada fluida yang tak termampatkan, hasil kali antara kelajuan aliran fluida dalam suatu wadah dengan luas penampang wadah selalu konstan (Kanginan, 2008). Sebagai gambaran, pada saat akan menyemprotkan air dengan menggunakan selang, ditemukan fenomena fisika yang aneh. Ketika ujung lubang selang ditekan, air memancar atau keluar semakin jauh. Sebaliknya ketika selang dikembalikan seperti semula maka jarak pancaran air akan berkurang.

Untuk lebih jelasnya dapat dilihat pada Gambar 3 dibawah ini, yang menunjukan suatu fluida ideal bermassa jenis $\rho$ memasuki pipa berluas penampang $A_{1}$ dengan kecepatan $v_{1}$ dan keluar pada pipa berluas penampang $A_{2}$ dengan kecepatan $v_{2}$.

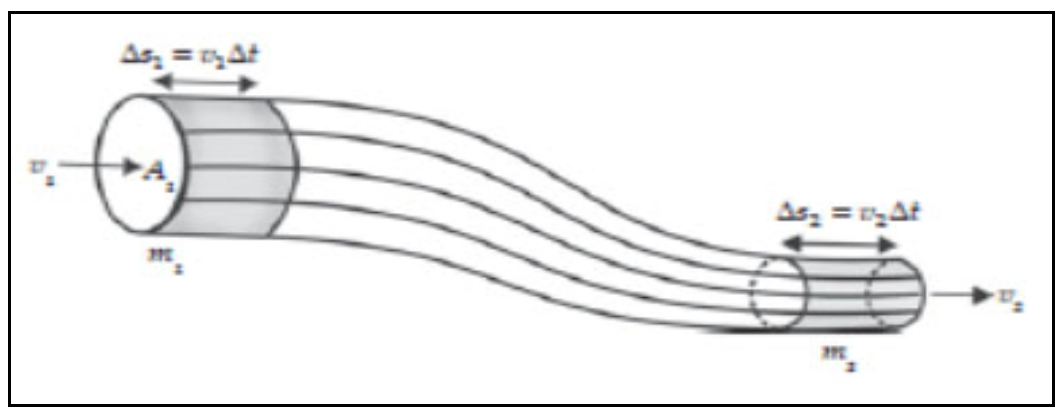

Gambar 3. Debit fluida yang masuk sama dengan yang keluar

Dari Gambar 2.12 diatas di dapat suatu persamaan yaitu sebagai berikut:

$$
\begin{aligned}
& \frac{m_{1}}{t_{1}}=\frac{m_{2}}{t_{2}} \\
& \frac{\rho V_{1}}{t_{1}}=\frac{\rho V_{2}}{t_{2}}
\end{aligned}
$$

$$
\frac{V_{1}}{t_{1}}=\frac{V_{2}}{t_{2}}
$$

Dari persamaan diatas dapat didefinisikan besaran baru yang disebut debit, yaitu volum fluida yang mengalir per satuan waktu. Jadi, debit $Q$ dapat dirumuskan sebagai berikut :

$$
Q=\frac{V}{t}
$$


Dengan ini dapat dinyatakan bahwa debit fluida yang memasuki pipa sama dengan debit fluida yang keluar dari pipa.

$$
\begin{aligned}
& Q_{1}=Q_{2} \\
& \frac{V_{1}}{t_{1}}=\frac{V_{2}}{t_{2}} \\
& \frac{A_{1} s_{1}}{t_{1}}=\frac{A_{2} s_{2}}{t_{2}}
\end{aligned}
$$

$$
A_{1} v_{1}=A_{2} v_{2}
$$

Persamaan (2.8) diatas dikenal dengan nama persamaan kontinuitas. Karena fluida inkonpresible (massa jenisnya tidak berubah) maka persamaan menjadi $A_{1} v_{1}=A_{2} v_{2}$. Untuk suatu pipa berbentuk silinder (penampang berbentuk lingkaran) dengan luas $A=\pi r^{2}=\frac{1}{4} \pi d^{2}$, maka persamaannya dapat ditulis sebagai berikut:

$$
v_{1} r_{1}^{2}=v_{2} r_{2}^{2} \text { atau } v_{1} d_{1}^{2}=v_{2} d_{2}^{2}
$$

\section{Hukum Bernoulli}

Ketika mencoba menutup lubang suatu selang di mana air sedang mengalir keluar maka akan terasa adanya gaya dorong atau tekanan dari air tersebut. Hal yang serupa juga terjadi ketika seseorang berdiri di tengah angin yang cukup besar. Pada fluida tak bergerak akan mempelajari hubungan antara tekanan dan kedalaman. Sekarang, bagaimana hubungan antara tekanan dan kecepatan di dalam fluida? Daniel Bernoulli telah membuktikan bahwa semakin besar kecepatan fluida, semakin kecil tekanannya dan begitu juga sebaliknya semakin kecil kecepatan fluida, semakin besar tekanannya. Pernyataan ini selanjutnya dikenal dengan asas Bernoulli. Asas Bernoulli menyatakan bahwa "Pada pipa mendatar (horizontal), tekanan fluida paling besar adalah pada bagian yang kelajuan alirannya paling kecil, dan tekanan yang paling kecil adalah pada bagian kelajuan alirannya paling besar” (Kanginan, 2008).

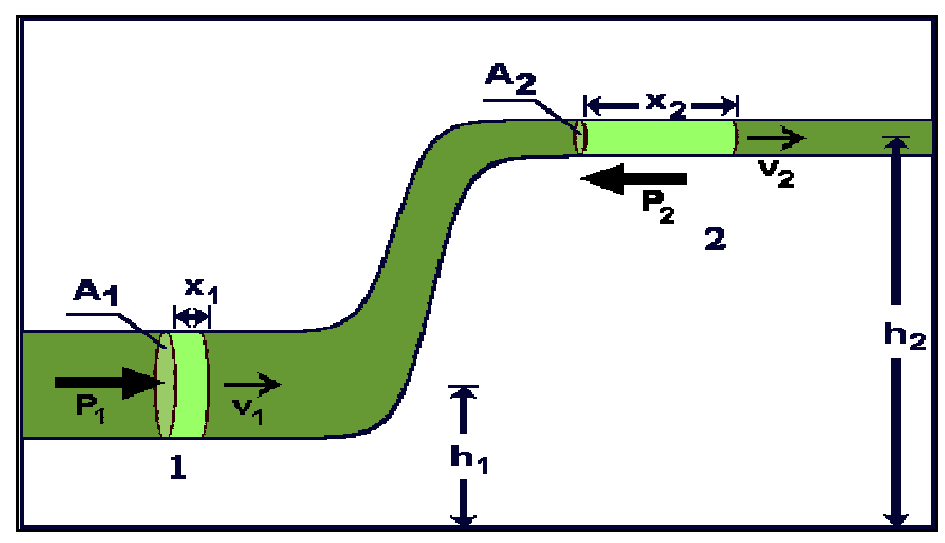

Gambar 4. Iluastrasi hukum Bernoulli

Pada Gambar 4 fluida pada luas penampang $A_{1}$ mengalir sejauh $x_{1}$, sehingga fluida pada luas penampang $A_{2}$ mengalir sejauh $x_{2}$, karena $A_{2}$ lebih kecil dari pada $A_{1}$ maka kecepatan aliran fluida pada luas penampang yang lebih kecil akan lebih cepat mengalirnya. Dalam penerapan fluida bergerak akan dipelajari teorema tentang usaha dan energi yang menyatakan bahwa usaha $W$ yang di lakukan suatu benda sama dengan perubahan energi mekanik benda $\triangle E M$, yang dirumuskan melalui persamaan $W=\triangle E M$ dan $W=\triangle E P+\triangle E R$.

\section{ANALISIS DAN PERANCANGAN} DFD Level 0

Pada DFD Level 0 ini terdapat dua buah entitas, yaitu entitas User dan Admin. DFD Level 0 ini juga terdapat satu buah proses yaitu Aplikasi Simulasi Berbasis Multimedia untuk 
Mekanika Fluida pada Fisika. Pada DFD Level 0 ini terdapat aliran data yang masuk dan aliran data yang keluar dari proses tersebut.

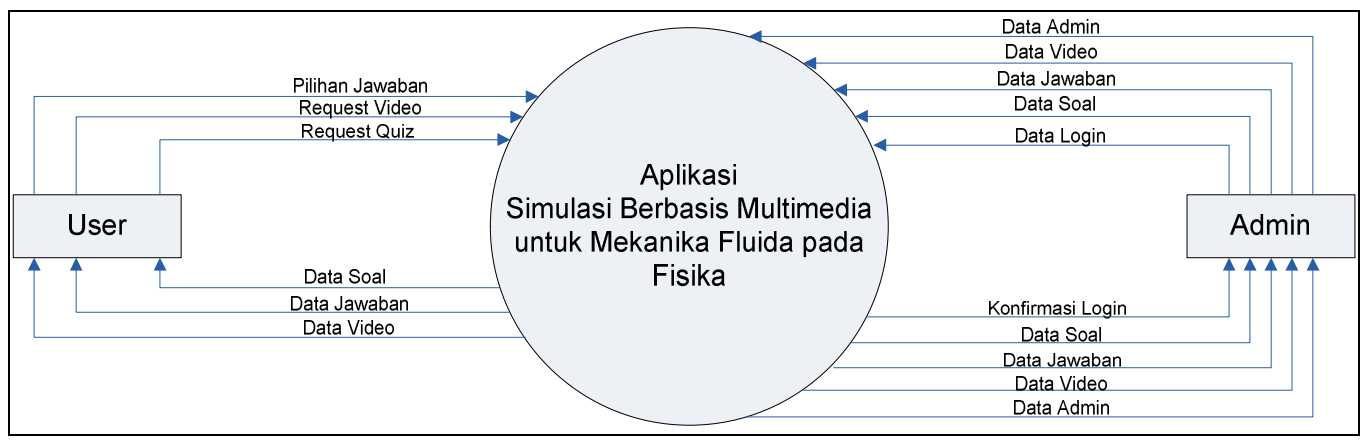

Gambar 5. DFD Level 0

\section{DFD Level 1}

Pada DFD Level 1 ini menjelaskan admin melakukan proses login yang datanya dikirim ke proses login. Admin dapat melakukan olah data soal dan jawaban kemudian olah data video dan olah data profil admin. Sementara untuk user dapat melakukan pengambilan data soal dan jawaban serta data video serta data admin yang diambil pada data store masingmasing yang kemudian di dalam proses diteruskan ke user. Proses yang terdapat pada user merupakan layanan multimedia, dimana layanan multimedia ini merupakan content multimedianya.

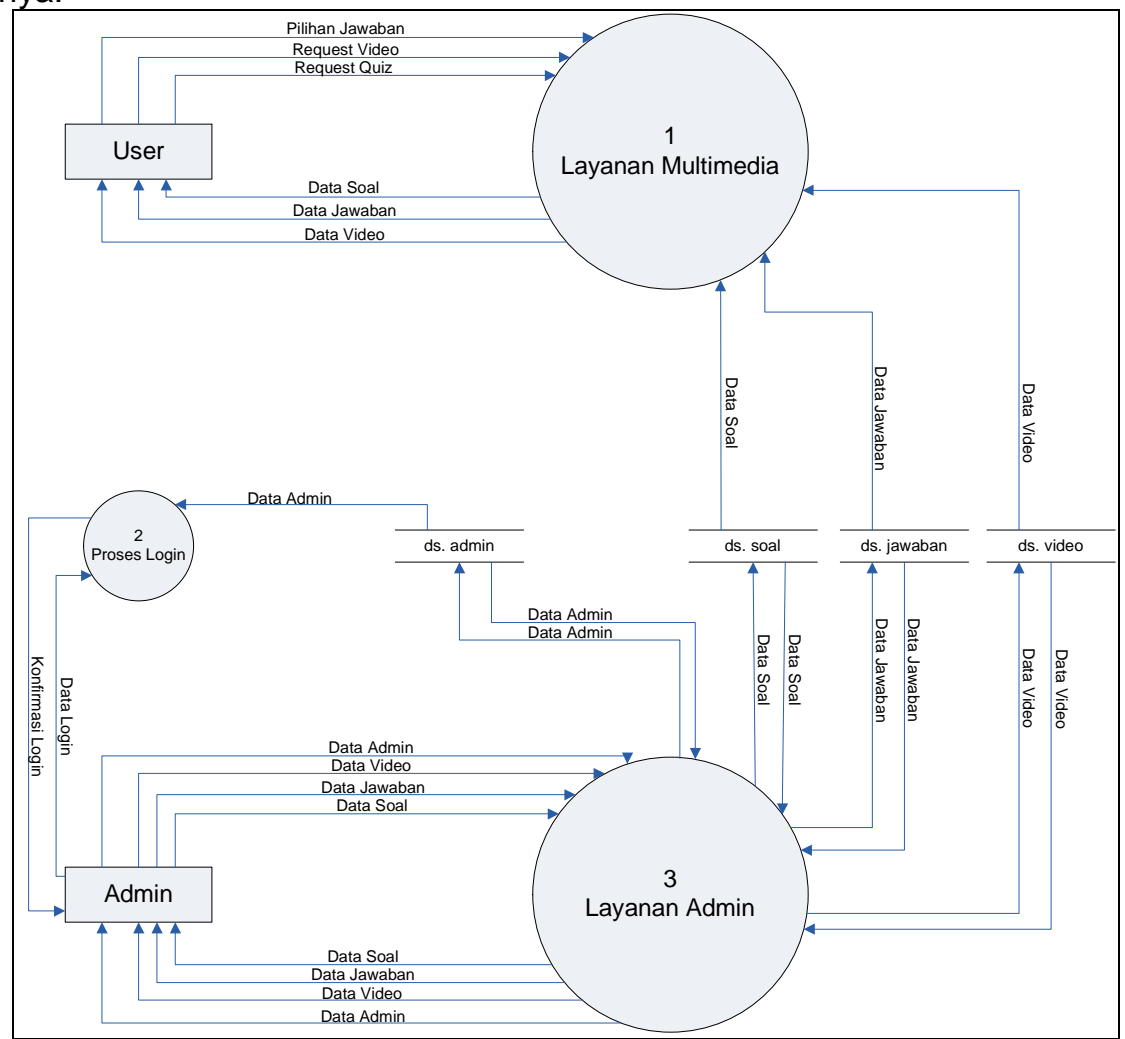

\section{IMPLEMENTASI}

\section{Halaman Home}

Halaman home merupakan halaman yang pertama kali dijumpai user ketika menjalankan aplikasi simulasi berbasisi multimedia untuk mekanika fluida pada fisika. Pada halaman ini berisi penjelasan konsep dasar mekanika fluida. 


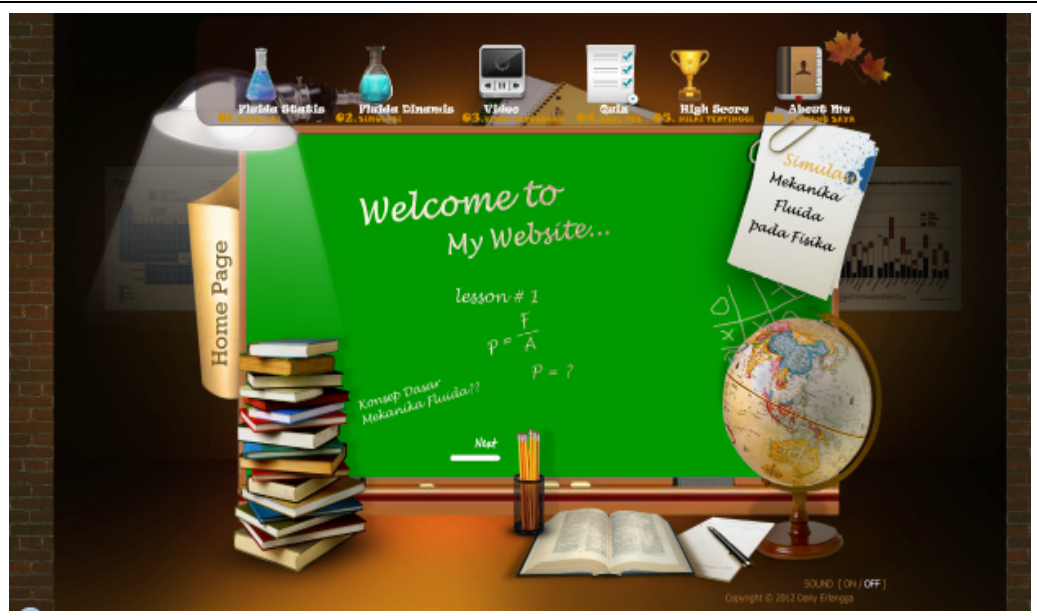

Gambar 7. Halaman menu utama (Home Page)

\section{Halaman Menu Fluida Statis}

Halaman fluida statis terdapat 2 pilihan menu yaitu menu hukum pascal dan menu hukum archimedes. Tiap menu yang akan dipilih akan menampilkan halaman dari menu tersebut.

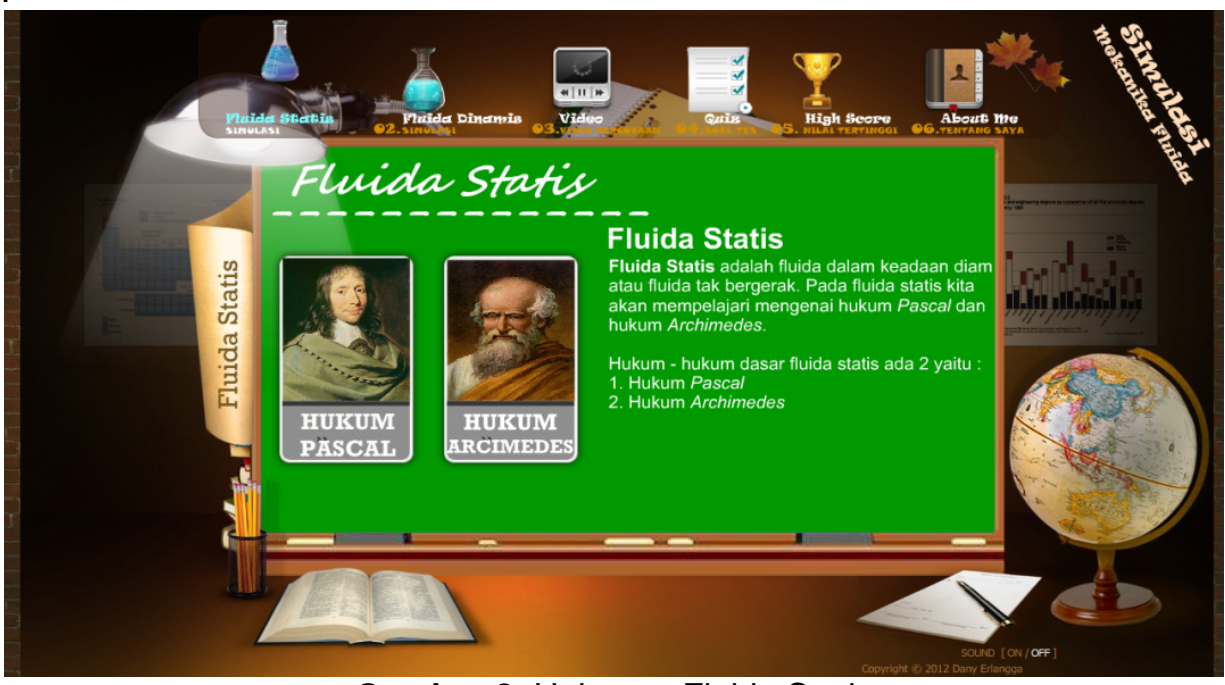

Gambar 8. Halaman Fluida Statis

Modul Program 1. ActionScript Link Navigasi pada Fluida Statis

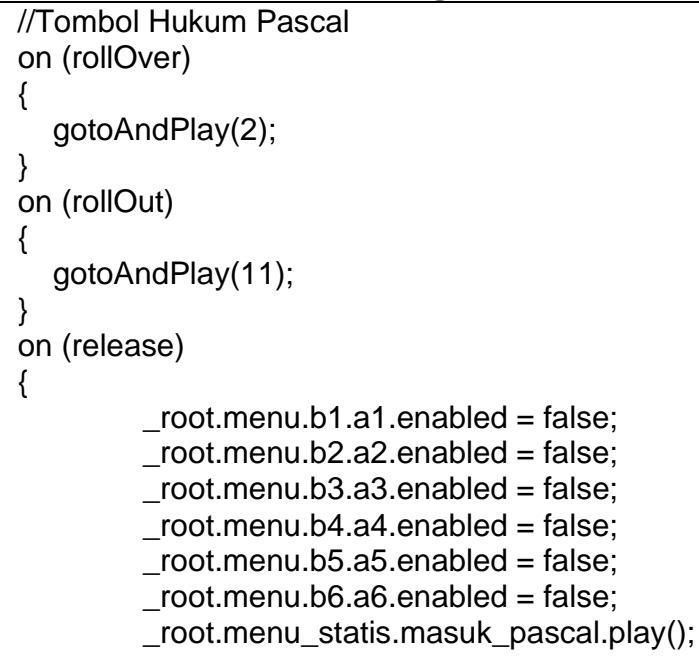




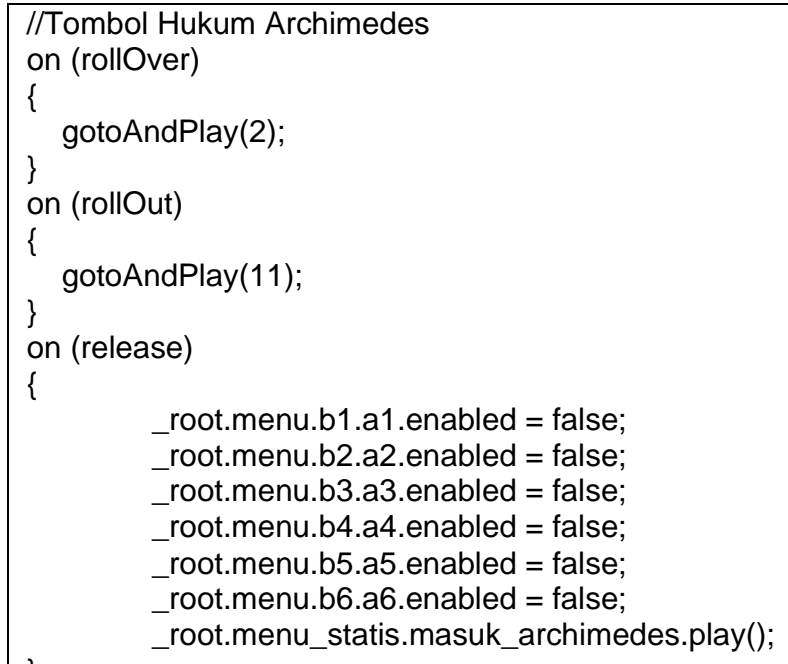

\section{Halaman Menu Hukum Pascal}

Tampilan halaman menu hukum pascal dapat dilihat pada gambar 9 .

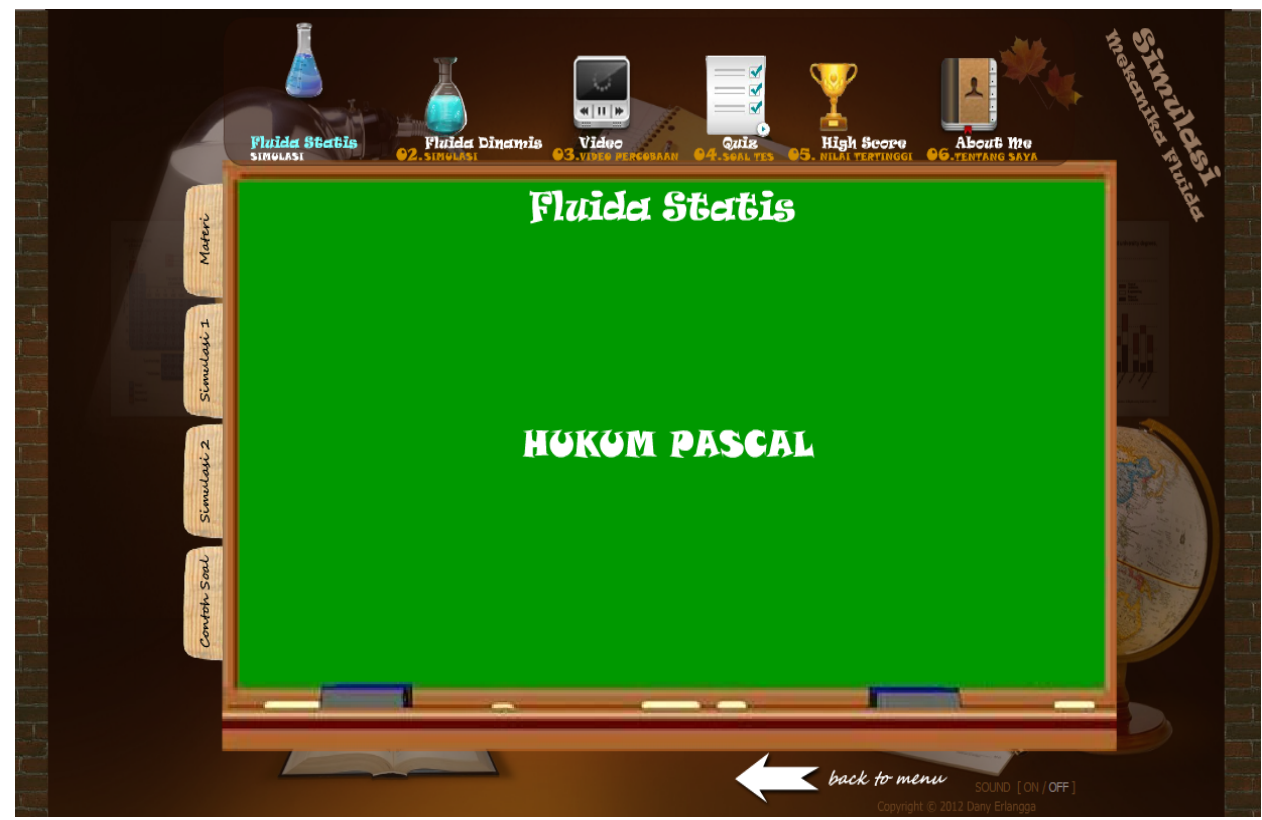

Gambar 9. Halaman Menu Hukum Pascal

Berikut adalah source code dari halaman menu hukum pascal:

Modul Program 2. ActionScript tombol materi hukum pascal

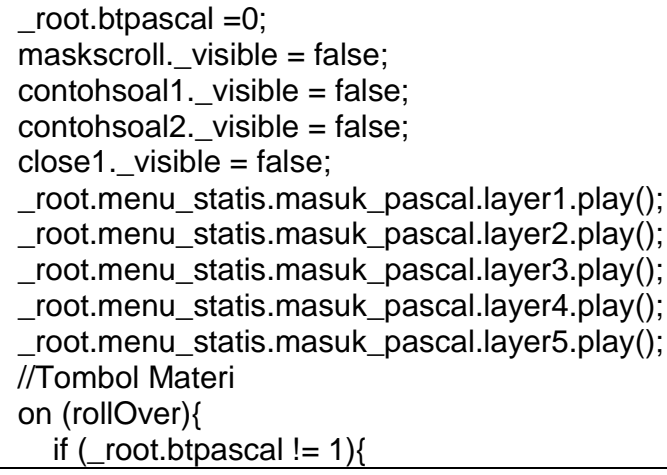




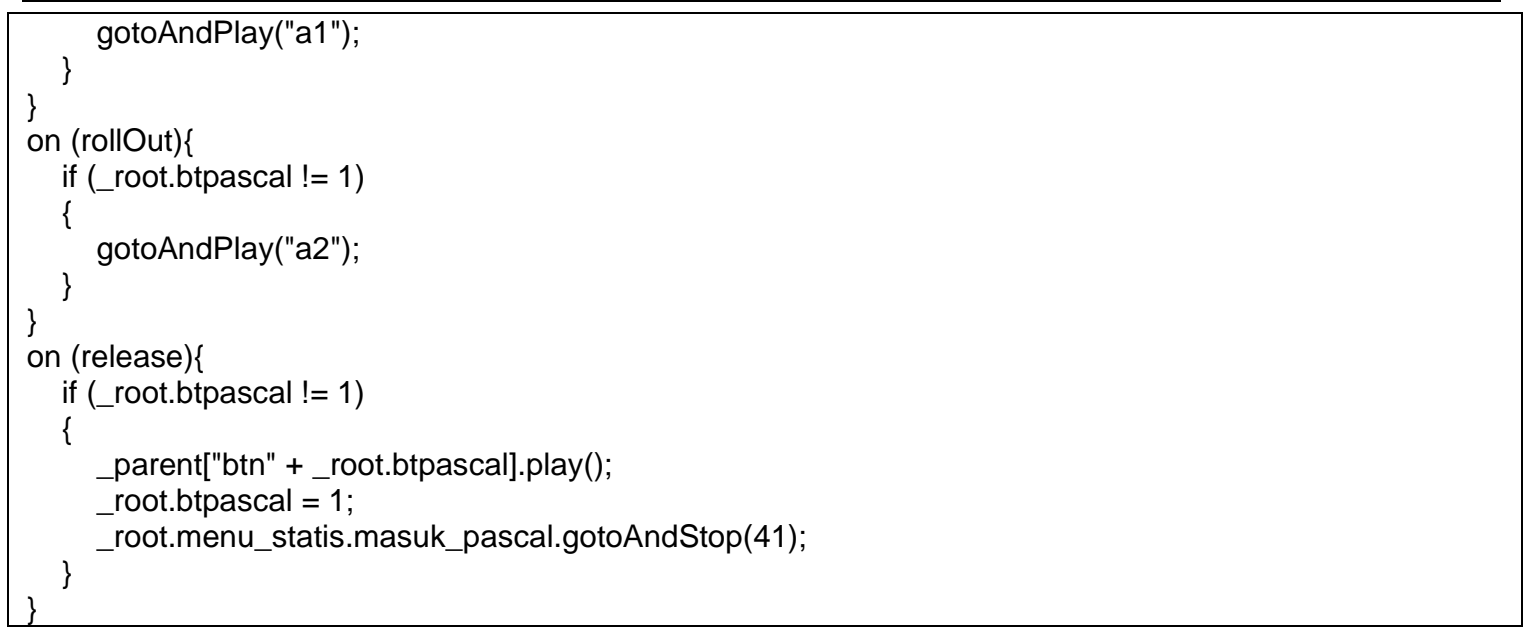

\section{Halaman Materi Hukum Pascal}

Halaman materi hukum pascal berisi penjelasan materi beserta gambar tentang hukum pascal. Terdapat scrollbar untuk menggeser lembar kerja.

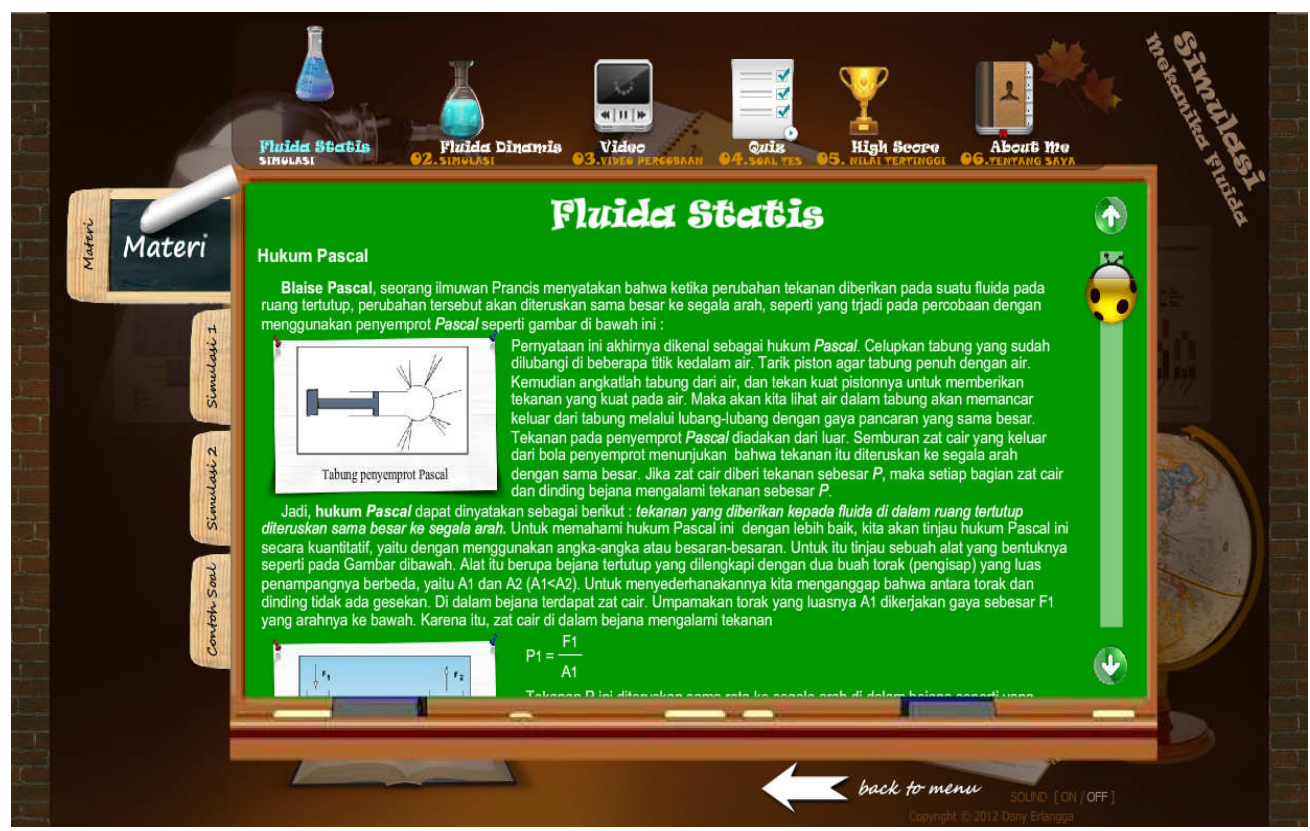

Gambar 10. Halaman Materi Hukum Pascal

\section{Halaman Materi Hukum Archimedes}

Halaman materi hukum archimedes berisi penjelasan materi beserta gambar tentang hukum archimedes. Terdapat scrollbar untuk menggeser lembar kerja. Tampilan halaman materi hukum archimedes dapat dilihat pada Gambar 4.13. 


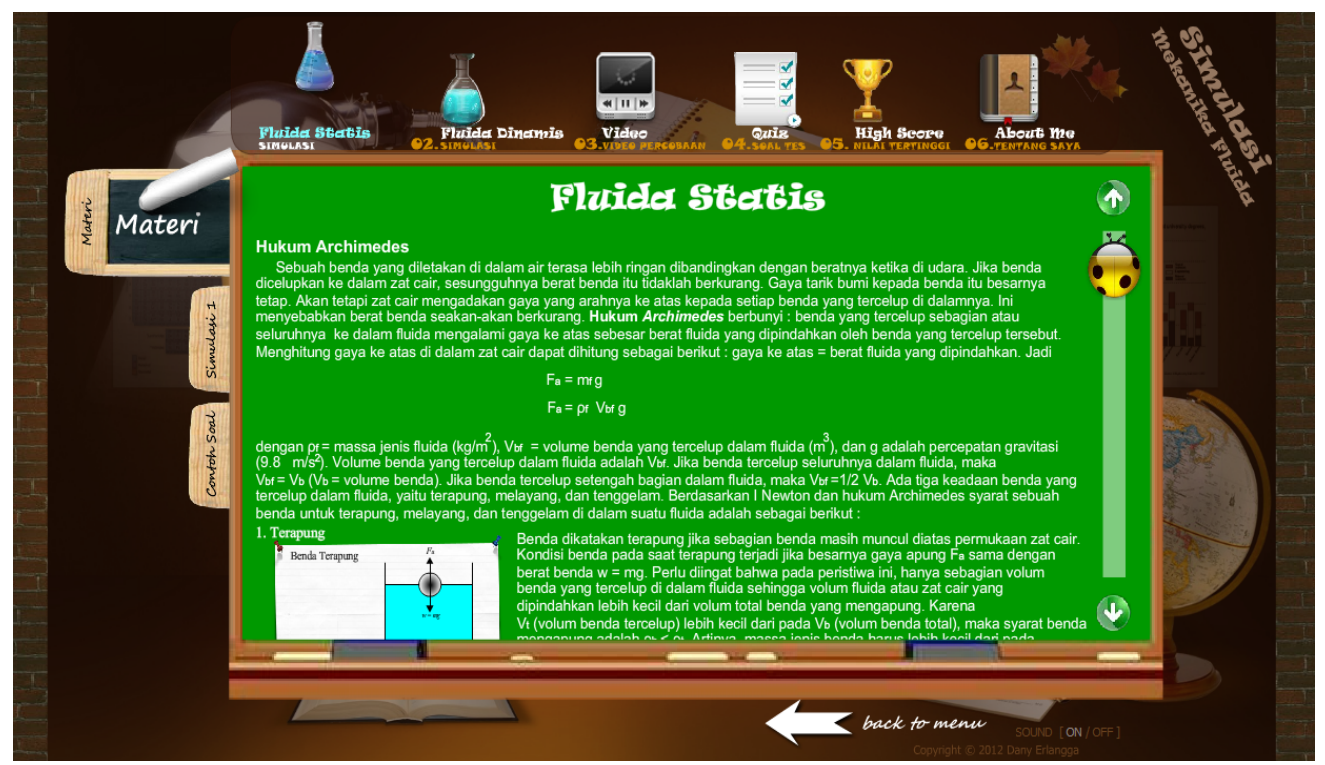

Gambar 11. Halaman materi Hukum Archimedes

Berikut adalah source code dari halaman materi hukum archimedes:

Modul Program 3. ActionScript tombol materi hukum archimedes

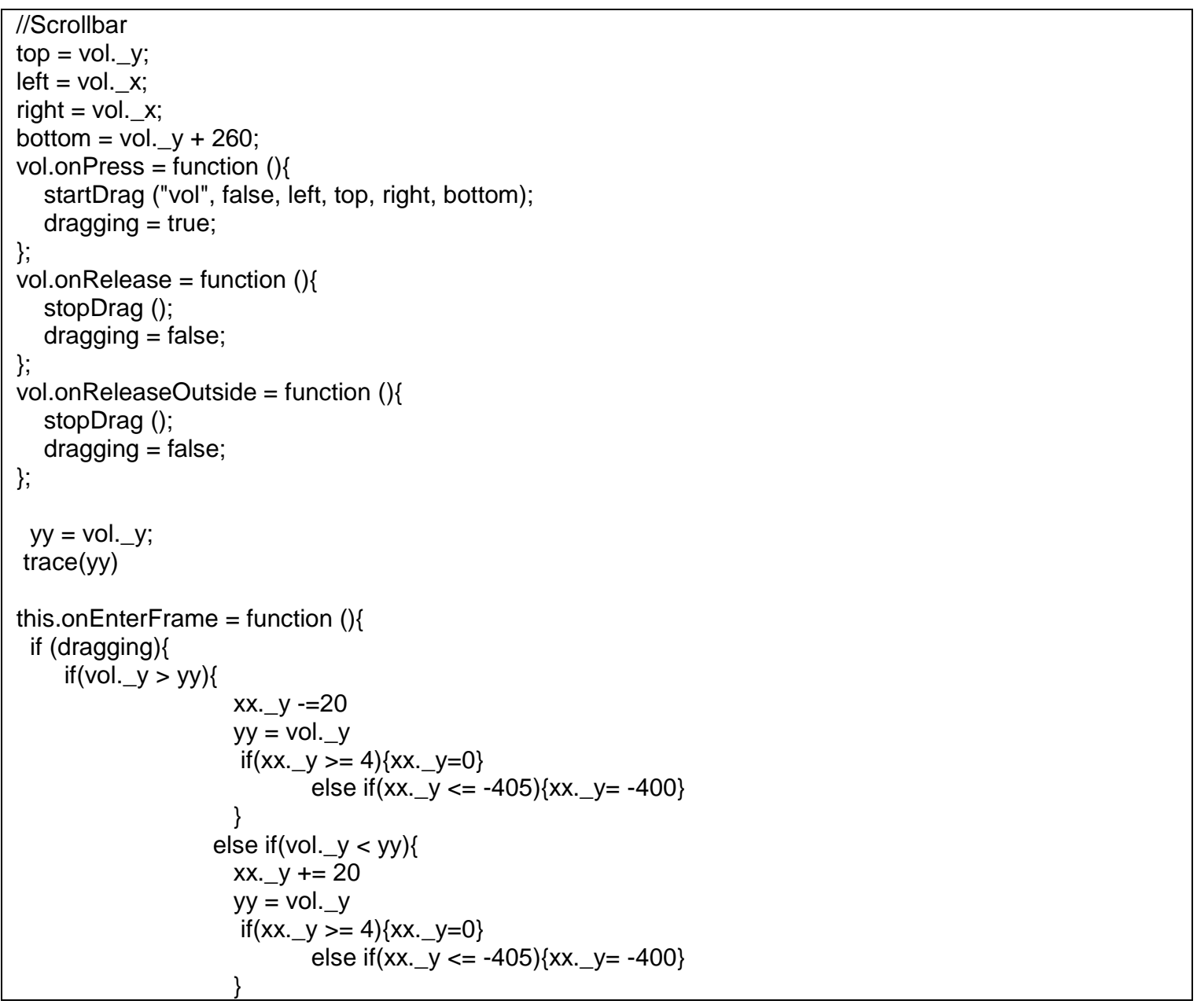




\section{Halaman Simulasi Hukum Archimedes}

Halaman simulasi hukum archimedes yaitu halaman simulasi untuk menentukan benda tenggelam, melayang, terapung, volum benda tercelup dalam zat cair, volum benda terapung diatas zat cair, gaya keatas, berat benda dalam zat cair, massa benda dalam zat cair dengan menginputkan benda yang digunakan, massa benda, zat cair yang digunakan, massa zat cair, massa benda, volum benda dan gravitasi.

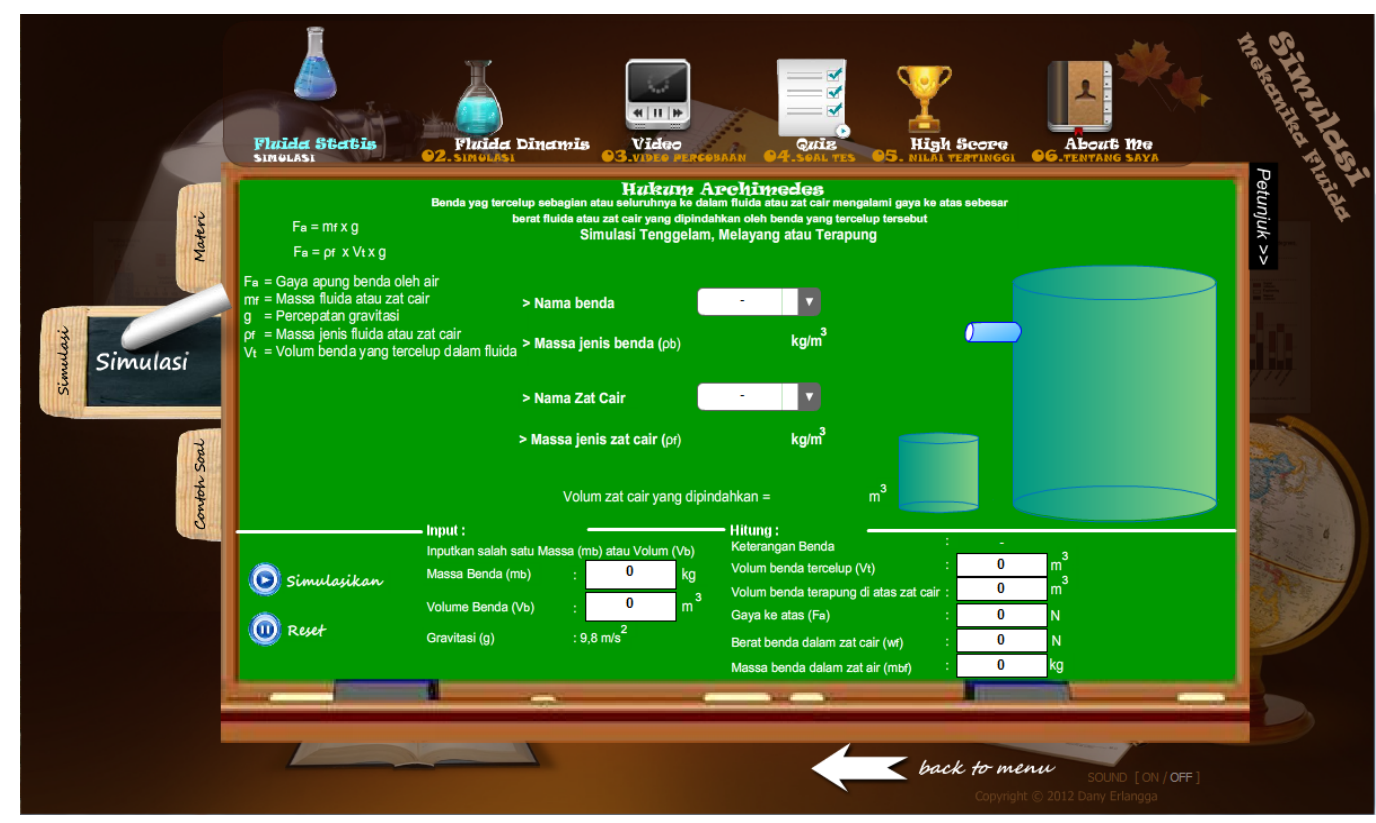

Gambar 12. Halaman Simulasi Hukum Archimedes Berikut adalah source code dari halaman simulasi hukum archimedes:

Modul Program 4. ActionScript tombol materi simulasi hukum archimedes

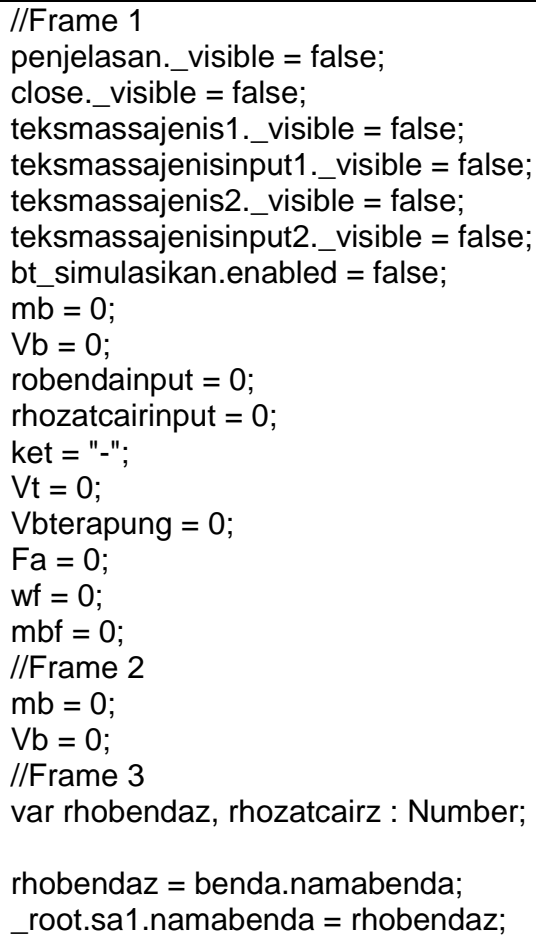




\section{PENUTUP \\ Kesimpulan}

Setelah mengimplementasikan tahapan analisis dan perancangan sistem telah berhasil dibuat Aplikasi Simulasi Berbasis Multimedia untuk Mekanika Fluida pada Fisika. Aplikasi ini membahas mekanika fluida dan 2 klasifikasi hukumnya, yaitu fluida statis dan fluida dinamis. Fluida statis membahas hukum pascal dan hukum archimedes, sedangkan fluida dinamis membahas hukum kontinuitas dan hukum bernoulli. Aplikasi ini bermanfaat sebagai sarana yang dapat membantu guru dalam menyampaikan materinya kepada siswa mengenai mekanika fluida dan dapat membantu seseorang dalam hal ini lebih difokuskan pada siswa tingkat SMA (Sekolah Menengah Atas) dalam memahami materi mekanika fluida.

\section{Saran}

Pada penelitian ini masih banyak terdapat kekurangan yang perlu diteliti lebih lanjut sebagai bahan untuk pengembangan sistem, beberapa saran yang diajukan berkaitan dengan pengembangan penelitian selanjutnya adalah sebaiknya materi mekanika fluida dapat diupdate, serta dapat memasukan rumus-rumus fisika ke dalam materi dan soal. Pada materi terdapat suara navigasi untuk membaca materi tersebut. Selain itu tes soal tidak hanya berupa pilihan ganda tetapi berupa essai.

\section{DAFTAR PUSTAKA}

Hartono, Jogiyanto, 1990, Analisis dan Disain Sistem Informasi, Andi Offset, Yogyakarta. Kadir, Abdul, 2003, Pengenalan Sistem Informasi, Penerbit Andi, Yogyakarta.

Kanginan, Marthen, 2008, Seribu Pena Fisika untuk SMA/MA kelas XI, Erlangga, Jakarta.

Komputer,Wahana, 2007, Membangun GUI Dengan Java Netbeans 6, Andi, Yogyakarta.

Kristanto, Andri, 2003, Perancangan Sistem Informasi dan Aplikasinya, Penerbit Gava Media, Jakarta.

Nugroho, Bunafit, 2004, PHP \& MySQL dengan Editor Dreamweaver MX, Andi Offset, Yogyakarta.

Pressman, Roger S., 2002, Rekayasa Perangkat Lunak: Pendekatan Praktisi jilid Dua, Penerbit: Andi Offset, Yogyakarta.

Ridwan, 1999, Pengantar Mekanika Fluida, Gundarma University.

Sridadi, Bambang, 2009, Pemodelan dan Simulasi Sistem, Informatika, Bandung.

Supiyanto, 2005, Fisika SMA untuk SMA kelas XI, Erlangga, Jakarta.

Sutanta, Edhy, 1996, Sistem Basis Data : Konsep dan Perannya dalam Sistem Informasi Manajemen, Penerbit Andi, Yogyakarta.

Sutarman, 2002, Membangun Aplikasi Web dengan PHP dan MySQL. Graha Ilmu, Jakarta.

Sutedjo, B., Nogroho, M.A., 2002, Algoritma dan Teknik Pemrograman Konsep, Implementasi dan Aplikasi, Andi Offset, Yogyakarta

Sutopo, A. H, 2003, Multimedia Interaktif dengan Flash, Graha IImu, Yogyakarta.

Suyanto, M., 2003, Multimedia : Alat untuk Meningkatkan Keunggulan Bersaing, Penerbit Andi, Yogyakarta.

http://handzmentallist,blogspot.com/2010/10/pengertian-erd-dan-normalisasi.html (diakses 19 Oktober 2011). 